\title{
THE EUROPEANISATION OF THE COOPERATION OF THE FEDERAL GOVERNMENT AND THE PARLIAMENT IN THE REPUBLIC OF AUSTRIA - A POLITICAL ANALYSIS
}

\section{Introduction}

The subject of this paper is the analysis of the cooperation of the Federal Government and the bicameral Austrian parliament in matters relating to Austria's membership in the European Union. Twenty years since the accession of Austria to the EU structures, its passing in 2015 encourages a reflection on the process of adaptation of this country to day-to-day functioning in the European Union, as well as on the challenges and difficulties, which emerged in political practice. An amendment of Austria's Constitution enacted a year before accession provide for the constructive cooperation of the executive and legislative authorities on activities within the EU, thus ensuring that the National Council (Nationalrat) and Federal Council (Bundesrat) have a decent impact on the European policy of the Federal Government ${ }^{1}$. The provisions introduced were meant, despite the ongoing process of Europeanisation, to protect the identity of the National Constitution and political principles. The amendment was designed to maintain the high constitutional position of the legislative power, "participation in the executive process of the federation", which, as it was pointed out by Paweł Sarnecki, is equipped with an unusually broad set of legislative and control competences over the executive power ${ }^{2}$.

The thesis of the paper assumes that upon accession of Austria to the European Union the bicameral parliament exercises the broad competence relating to control over the activities of the Government in matters of the EU membership it was granted only to a limited extent, which reinforces the dominance of the Federal Government in the EU decision-making processes. Significant research problems, which are the

\footnotetext{
$1 \quad$ Bundesverfassungsgesetz v. 21.12.1994 in der Fassung der Wiederverlautbarung des Bundes-Verfassungsgesetz vom 1. Januar 1930 (in der Fassung vom 7. Dezember 1929) http://www.verfassungen.de/at/at18-34/index29.htm (data dostępu: 1.09.2015 r.).

2 P. Sarnecki, System konstytucyjny Austrii, Warszawa 1999, s. 48.
} 
subject of the study, include the following questions: How do Member States adapt to participate in the EU decision-making process? What model of cooperation of the legislative and executive authorities in the matters relating to state's membership in the European Union has been adopted in Austria? Are the measures of parliamentary control over the actions taken by the Government in the EU forum provided both in the constitution and in the regulations of both chambers of the Parliament followed? What are the causes of decreased importance of the Parliament in making European policy in Austria?

In the first place, we should determine, what is the essence of the adaptation of an EU Member State to participate in the decision-making process. Then the solutions adopted in Austria are presented, which should supposedly guarantee a high degree of control of the legislature over the executive power in matters of European integration. In the third and final part of the paper we discuss political practice and the reasons for the de facto withdrawal of the Parliament from making the European policy of Austria and from control of the Federal Government in this area.

The term "Europeanisation" used in the paper is defined as a systematic process of adaptation of a Member State to the requirements of the political and institutional system of the European Union, which stimulates changes to the structure and functioning of the national state ${ }^{3}$. The higher is the degree of noncompliance of the regulations at the national level (institutions, policies, political processes) to the regulations at the European level, the greater is the pressure from the EU to make changes in a Member State. As a result of the process called topdown Europeanization, public authorities accept the new duties and new vertical and horizontal decision-making mechanisms that are established, often leading to reduction of existing traditional segments of the state apparatus ${ }^{4}$.

\section{Adaptation of a Member State to participate in the EU decision-making process}

The applicable principle of procedural autonomy, enshrined in Article 4, section 2 of the Treaty on European Union, as amended by the Treaty of Lisbon, confirms that the organisation and the method of operation of the public administration as well as the choice of measures to fulfil the obligations under the rules of the Community law depends on the Member State, which is committed to the effective execution of specific tasks by competent institutions, in accordance with national regulations ${ }^{5}$.

3 T. Börzel, Demokratien im Wandel der Europäisierung, (w:) Demokratien in Europa: Der Einfl der europäischen Integration auf Institutionenwandel und neue Konturen des demokratischen Verfassungsstaates, Hrsg. I. Katenhusen, W. Lamping, Opladen 2003, s. 186,

$4 \quad$ K. Kubuj, J. Wawrzyniak, Wstęp, (w:) K. Kubuj, J. Wawrzyniak (red.), Europeizacja konstytucji państw Unii Europejskiej, Warszawa 2011, s. 13.

5 A. Nowak-Far, Stosowanie acquis de l'Union przez administrację publiczną państwa członkowskiego, (w:) J. Czaputowicz (red.), Administracja publiczna. Wyzwania w dobie integracji europejskiej, Warszawa 2008, s. 114. 
A symptom and a result of the ongoing process of Europeanisation and the accommodative mechanisms implemented an individual institutional, procedural and coordination mechanism both within the government itself and within the relationships between the government, parliament and local government bodies developed in each EU Member State ${ }^{6}$. The unique solutions relating to the coordination of the European policy adopted in each country are derived from different conditions. The model developed in each country is significantly affected, in the first place, by the normative and institutional nature of the EU including existing EU decision-making procedures, secondly, by the constitution and governance and division of responsibilities between central and local government units, thirdly, by the current stage of relationships between the given country and the EU and fourthly, by a tendency to provide some institutional and procedural solutions perceived as a security mean for protecting the interests of the given state in the $\mathrm{EU}^{7}$.

A robust and effective mechanism for coordinating European policy is designed to meet many needs relating to membership of the given country in the European Union. The main challenge is: 1) effective, robust and timely conveying of views in the EU decision-making bodies; 2) providing democratic support for the positions adopted by the government and made at the EU forum; 3) ensuring the efficiency and consistency of implementation of the EU law in the given Member State; 4) guaranteeing a proper response of the given Member State in the event of a case before the ECJ and the Court of first instance ${ }^{8}$. Finding the optimum solution for public decision-making in European matters guarantees an influence on directions of policies and activities of the European Union and the use of all the opportunities arising from membership of the state in the EU.

A trend observed among the Member States is a progressively strengthened position of the government in the structure of the constitutional bodies, including an increased involvement of the prime minister in matters related to integration of the states to the EU. The extended competences of the EU are accompanied by a continuous adaptation of the Member States, which leads to a transfer of the tasks relating to the policy of the European Union to the executive (national government). This process is a result of an accumulation of several factors. First, the governments have most legal and administrative instruments to ensure cooperation; second, the government as an emanation of parliamentary majority expresses the will of the governing parties and of most citizens; third, it operates in an area defined by the needs of society as well as by the values and characteristics of a specific political

6 G. Rydlewski, Systemy administracji publicznej w państwach członkowskich Unii Europejskiej, Warszawa 2007, s. 67.

$7 \quad$ T. Kołodziej, Decydowanie w sprawach stanowiska państwa w relacjach z UE, (w:) G. Rydlewski (red.), Decydowanie publiczne. Polska na tle innych państw członkowskich Unii Europejskiej, Warszawa 2011, s. 338.

8 J. Miecznikowska, Unia Europejska a problem koordynacji polityk unijnych - europeizacja administracji publicznej państw członkowskich, (w:) R. Mieńkowska - Norkiene (red.), Koordynacja polityk unijnych w Polsce, Warszawa 2009, s. 42-43. 
culture ${ }^{9}$. A material pressure is also caused by technocratisation of the EU system and the priority of efficient, robust and consistent operation, which is meant to ensure the participation of a Member State in the EU decision-making process.

Due to the European function performed by the national parliaments, which is a compilation of the two basic functions of the legislation: a legislative and a control one, a new decisive area of the national legislature is established in the EU countries, which constantly changes, transforms and evolves ${ }^{10}$. In the opinion of Jarosław Szymanek, it does not change the fact that a unit participating in the mechanism of decision-making between the Member State and the EU is the national executive. The scope of operation of the parliament set by the European function represents only an imperfect form of minimising the so-called EU democratic deficit ${ }^{11}$ and a compensation for the lost omnipotence in making laws as a consequence of the transfer of the legislative powers of the national parliaments to EU bodies.

The representatives of the governments, who represent the Member States in the intergovernmental EU institutions, are responsible for their positions before their national parliaments, but the degree of control of the legislative over the executive is varied and depends on the internal legislation of the Member State concerned. The solutions for the scope of parliamentary decisions in EU matters adopted in Austria grant particularly great decisive power to the first parliamentary chamber.

\section{The cooperation of the Federal Government with the National Council and the Federal Council in European integration matters de iure}

The Constitution of the Republic of Austria (Bundesverffasunggesetz B-VG), in Art. 23 c, Art. 23 e and Art. 23 h-23 k k $^{12}$, and the frequently amended (recently in May 2015) regulations of the National Council ${ }^{13}$ and the Federal Council ${ }^{14}$, define the framework of cooperation of the Federal Government and the two chambers of the Parliament in matters related to Austrian membership in the EU. The socalled "Vienna model" grants, on the one hand, wide powers to the legislative (the

T. Kołodziej, Decydowanie w sprawach stanowiska państwa w relacjach z UE, (w:) G. Rydlewski (red.), Decydowanie publiczne. Polska na tle innych państw członkowskich Unii Europejskiej, Warszawa 2011, s. 331.

10 J. Szymanek, Decydowanie parlamentarne, (w:) G. Rydlewski (red.), Decydowanie publiczne. Polska na tle innych państw członkowskich Unii Europejskiej, Warszawa 2011, s. 76.

11 Ibidem, s. 79.

12 Bundes-Verfassungsgesetz (B-VG)StF: BGBI. Nr. 1/1930 (WV) idF BGBI. I Nr. 194/1999 (DFB) https://www. ris.bka.gv.at/GeltendeFassung.wxe?Abfrage=Bundesnormen\&Gesetzesnummer=10000138 (data dostępu: 1.09.2015 r.).

13 Bundesgesetz über die Geschäftsordnung des Nationalrates (Geschäftsordnungsgesetz 1975. BGBI. I Nr. 62/2015 http://www.ris.bka.gv.at/Dokumente/BgblAuth/BGBLA_2015_I_62/BGBLA_2015_I_62. (data dostępu: 5.09.2015 r.).

14 Gesamte Rechtsvorschrift für Geschäftsordnung des Bundesrates 1988, BGBI. I Nr. 53/2015 https://www. ris.bka.gv.at/GeltendeFassung.wxe?Abfrage=Bundesnormen\&Gesetzesnummer=10000976 (data dostępu: 5.09.2015 r.). 
possibility of parliamentary intervention, thus of control over the European policy made by the Federal Government), while on the other, it obliges the legislative and the Federal Government to cooperate constructively in matters of integration ${ }^{15}$.

Pursuant to Art. 23c, section 2 of the BVG, the Federal Government is obliged to obtain the consent of the Main Commission of the National Council for the selection of candidates for some offices in the EU institutions and to notify both the Main Commission of the National Council and Federal President of the decision made. In addition, the Government is responsible for informing both chambers of the Parliament of electing the members of the European Economic and Social Committee, after hearing the proposals of the statutory representatives of various groups of the economic and social environment (Art. 23c, section 3 of the BVG) as well as of the members of the Committee of the Regions proposed by federal states, the Austrian Association of Cities and Towns and the Austrian Association of Municipalities (Art. 23c, section 4 of the BVG).

Pursuant to Art. 23e, section 1 of the BVG, a competent member of the Federal Government should report details of all activities within the EU to the National Council and the Federal Council. The National Council and the Federal Council should be informed about draft decisions of the EU Council and the European Council related to any change in voting method from unanimity to a qualified majority.

The National Council and the Federal Council have the right to adopt a position relating to any activities within the European Union. Thus the Constitution guarantees to the Parliament a mechanism of wide control over the European policy made by the executive.

According to Art. 23k, section 2 and section 3 of the BVG, the National Council performs its tasks relating to integration matters $(23 \mathrm{e}, 23 \mathrm{f}$, section $4,23 \mathrm{~g}$ and 23j, section 2), primarily, through its Main Commission of the National Council or through the Special Standing Subcommittee for the EU, to which the Main Commission delegates some competences, deciding on its scope (Art. 55, section 3 of the BVG, Art. 29-31e of the regulations of the National Council). According to Art. 55, section 1 of the BVG, its composition reflects the allocation of seats in the National Council to different political parties, and, in the opinion of P. Sarnecki, the Main Commission itself is "probably the most visible manifestation of entering of the Austrian Parliament beyond a purely legislative competence"16. The President of the Main Commission is the President of the National Council. In the Standing Subcommittee for the EU at least one representative of a party represented in the Main Commission is required. In the opinion of Jan Barcz, entrusting the activities within the EU to the Main Commission is an expression of pragmatism and striving for ensuring effectiveness of the decision-making process within the competence

\footnotetext{
15 J. Barcz, Austria w Unii Europejskiej. Problemy prawne w procesie akcesyjnym, Opole 2001, s. 114.

16 P. Sarnecki, System konstytucyjny..., op. cit., s. 51.
} 
granted to the National Council, because the entire chamber would not be able to effectively and quickly address a specific matter ${ }^{17}$.

According to the regulations of the Federal Council and pursuant to Art. 23k, section 3 of the BVG, the tasks of this body are entrusted to the Commission for the European Union. Nonetheless the Federal Council may decide to perform its tasks in pleno, when at the beginning of the parliamentary session at least a half of the representatives of three federal states represented on the Committee for the European Union demands adopting a position concerning the activities within the EU by the Federal Council (Art. 13a of the regulations of the Federal Council).

The National Council may present a position concerning the intent within the $\mathrm{EU}$, which is to be put in practice in the form of a federal act or in the form of a directly applicable regulation, to a competent member of the Federal Government. Such a position is binding during the negotiations and in the voting procedures within the European Union, and a minister may withdraw from it only in exceptional circumstances, referring to the "overriding reasons arising from the integration and foreign policies" (Art. 23e, section 2). The rationale for withdrawal is very general, which undoubtedly gives the Federal Government considerable leeway. A possibility of withdrawal of a given minister from the position adopted by the National Council imposes previous consultations on the legislative and the executive authorities and makes the National Council deal with the matter again. If a minister withdraws from the position adopted by the National Council, he/she is obliged to explain the reasons for such action. The regulations of the National Council provide the possibility of acknowledgement or rejection of a report from the competent member of the Federal Government by the National Council.

If a matter is considered again by the National Council, then, if an EU legal act in the preparatory stage leads to any change to the current federal constitutional law, a withdrawal by the Government is possible only if the National Council does not object to this in due course (Art. 23e, section 3 of the Constitution). In such circumstances a competent federal minister is bound to reach an agreement with the National Council, so it does not refer to the right of absolute veto.

Positions are adopted by the Federal Council, in accordance with Art. 23e, section 4 of the Constitution, when the implementation of an action within the European Union requires a federal constitutional law, which requires the consent of the second chamber of the Austrian Parliament, or when the adopted constitutional laws restrict the legislative and administrative powers of the federal states (Art. 44, section 2 of the Constitution). The position is lodged in writing and forwarded immediately by the President of the Federal Council to the Chancellor, to Minister of

17 J. Barcz, Parlament a Unia Europejska analiza prawna na przykładzie doświadczeń Austrii, Warszawa 1999, s. 18. According to the regulations of the National Council, four special sessions dedicated to the EU matters ( $A k-$ tuelle Europastunden) in the first chamber of the parliament and two debates for summarising the European Council meetings based on experiences of members of the Federal Government (EU-Erklärungen), are held. 
Foreign and European Affairs, to a competent federal minister and to all the deputies to the Federal Council, to the President of the National Council, to the parliaments of the federal states, to the heads of governments of the federal states and to the Austrian members of the European Parliament. In the case of binding position a competent federal minister, while he or she is bound by it both during negotiations and in voting in the EU Council, may withdraw from it, if any overriding reasons relating to integration and foreign policies exist. However in case of qualified binding position, a minister may withdraw from it only if the Federal Council does not raise an objection within a strictly defined time period. In this situation, as in the case of proceedings before the National Council, a competent federal minister is required to provide the Federal Council with a report and an explanation of reasons for the withdrawal. The Constitution does not provide any mechanisms for consultation with the Federal Council, if a federal minister informs about the intent to withdraw from the binding position adopted by the Federal Council. On request of the Federal Council a competent ministry is only obliged to inform the Council about further operations.

Art. 23e amended by the recent amendments to the Federal Constitution and adopted after the Treaty of Lisbon in July 2010 entered into force, extended the responsibility of the Federal Government before the Federal Council and limited the possibility of free decision-making and taking free actions, which could entail the need to change constitutional law, by the government representative at the EU meeting. Thus protection of the federal nature of the Austrian State has been guaranteed and dependency on the National Council dominated by parties has been reduced.

Art. $23 \mathrm{f}$, section 1 of the BVG provides that the National Council and the Federal Council have the right to exercise the powers granted by the treaty law to the national parliaments. At the beginning of the year, a competent minister informs both chambers of the Parliament about the planned steps of the Council and the Commission and about the future position of the Government towards these intents. By virtue of Art. $23 \mathrm{f}$, section 4, the National Council and the Federal Council have the right to express their expectations, by informing the EU institutions about them in appropriate statements.

Pursuant to Art. 23i of the Constitution amended as a result of the Lisbon Treaty, a competent federal minister informs both the National Council and the Federal Council sufficiently in advance about the Council's decision concerning changing the voting system (the procedure laid down in Art. 48, section 7 of the TFUE). A transition from unanimity to qualified majority as well as change to the legislative procedure from a special one to an ordinary one (the so-called passerelle) requires an approval of both chambers of the Austrian Parliament, expressed by a majority of two thirds of votes with a quorum of at least a half of the statutory number of members, which is the majority required to amend the Constitution. Szymon 
Pawłowski underlines that in this way a significant strengthening of the position of the Parliament related to the procedure contained in Art. 23 e of the BV-G has been introduced, because the Federal Government cannot adopt a position other than the one shown by both chambers of the Parliament ${ }^{18}$. Art. $23 \mathrm{~g}$ of the BVG amended pursuant to the Treaty of Lisbon provides for a separate and independent commitment of the National Council and the Federal Council in preventive control over the EU draft legislation for compliance with the subsidiarity principle. Both chambers have the right to adopt a position, pointing to a possible breach of the subsidiarity principle by a legislative proposal. Pursuant to Art. 23h of the BVG, each of the two chambers of the Parliament may, via the Federal Chancellor, make a complaint (a follow-up complaint) against the immanent breach of the subsidiarity principle by the EU institutions to the Court of Justice.

\section{The cooperation of the Federal Government with the National Council and the Federal Council in European integration matters de facto}

Political practice shows that Parliament in Austria exercises the granted rights to influence state European policy only to a small extent. The formulation of strategies and the decision-making process within the EU in Austria has been gradually dominated by the central executive and the central administration. At least in the first years of Austria's membership both the National Council and the Federal Council relatively often adopted positions binding for the competent ministers during decision-making process in the EU. In 1995 the Main Commission of the National Council adopted a record number of 18 positions, but a year later it adopted less than half that number, just 7. In the first period after Austria's accession to the EU both the frequency of meetings of the Main Commission and the number of the positions adopted in EU matters was high. Over time, however, activity of the National Council in this field noticeably decreased, which is shown in table 1 . In the years 2003-2004 and 2006-2008 the Main Commission did not adopt any position binding the Federal Government concerning activities related to the EU. During the 24th parliamentary term of the National Council the Main Commission adopted only one or two positions a year ${ }^{19}$. izacja konstytucji państw Unii Europejskiej, Warszawa 2011, s. 49.

19 J. Pollak, P. Slominski, Zwischen De- und Reparlamentarisierung - der österreische Nationalrat und seine Mitwirkungsrechte in EU-Angelegenheiten , "Österreischische Zeitschrift für Politikwissensschaft" 2009 , nr 2, s. 201. 
The Europeanisation of the cooperation of the Federal Government...

Table 1. Activity of the Main Commission in EU matters

\begin{tabular}{|c|c|c|}
\hline Term of the National Council & $\begin{array}{c}\text { Number of sessions dedicated } \\
\text { to EU }\end{array}$ & Binding positions \\
\hline 20th 1995-1999 & 32 & 13 \\
\hline 21st 1999-2002 & 17 & 1 \\
\hline 22nd 2002-2006 & 21 & 0 \\
\hline 23rd 2006-2008 & 8 & 7 \\
\hline 24th 2008-2013 & 28 & 0 \\
\hline 25th 2013- & 10 & 4 \\
\hline
\end{tabular}

Source: http://www.parlament.gv.at (7/09/2015)

Activity of the Federal Council is equally law. Since 1995 it has adopted three positions (Stellungnahme des EU-Ausschusses des BR) and 22 justified statements (Begründete Stellungnahme des EU-Ausschusses des BR). The Commission for the EU by the Federal Council met with varying frequency: in 2007 only one session was not held, in 2008 and 2009 eight meetings were held, in the following years the average frequency of the Commission's deliberations increased to 10-11 times a year ${ }^{20}$.

We can indicate three reasons for a small commitment of the Austrian Parliament in consultation with the Federal Government on matters relating to the EU. It is certainly an expression of political pragmatism, because the binding position adopted by the Parliament unnecessarily weakens a competent minister during the dynamic negotiations within the EU. The negotiations of the regulations on the transport of the animals in the first year of Austria's membership in the European Union ended with a political defeat, which showed weakness in the practice of issuing binding instructions a representative of the Austrian executive by the National Council during the negotiations in the EU Council. The Austrian minister of agriculture bound by the position of the National Council could not accept a compromise proposed by the EU (there was no timely consent of the Main Commission of the National Council), and, eventually, the EU Council by qualified majority of votes adopted the regulations less acceptable in the perspective of the Austrian priorities ${ }^{21}$.

20 http://www.parlament.gv.at/PAKT/VHG/BR/A-EU-BR/A-EU-BR_00001_00037/index.shtml\#tab-Uebersicht (data dostępu: 10.09.2015 r.).

21 G. Falkner, Zur „Europäisierung” des österreichischen politischen System, (w:) H. Dachs (Hg.) Handbuch des politischen Systems Österreichs, Wien 2003, s. 87. 
An explanation for the passive attitude of the National Council is theoverloadingof the Parliament with excessive information from the EU, which is emphasised by Heinrich Neisser (during the 21st term of the National Council there were as many as 75000 documents), great difficulties occurred in processing and selecting data in consideration of their actual weight and their importance for the Austrian European policy ${ }^{22}$. The instruments of strong parliamentary control (provided for in the Constitution) are marginally used, which results from both EU practice and party convergence in the Government and in the Parliament, which strongly weakens the power of the latter. A result of the integration of Austria to the EU structures is marginalisation of the political role of the legislative in the decisionmaking processes in the EU, which is a consequence of recognising the national executive power as an authority fully legitimate to represent the Member State.

An additional element supporting the strong position of the Government towards the Parliament is the model of cooperation between two political parties, that is, the Christian Democrats and the Social Democrats, forming great coalitions (after accession to the EU, except in the years 2000-2006). The Government enjoys the a strong support of a majority of the members of the National Council (see table 2). Binding positions may be adopted by the Main Commission with the consent of the whole fraction of the governing parties, and they have confidence in the European policy of the Government. The Main Commission of the National Council becomes only a stage for the opposition parties used for expressing their opinions.

Table 2. Ruling majority in the National Council

\begin{tabular}{|c|c|c|}
\hline Chancellor and term & $\begin{array}{c}\text { Political composition of the } \\
\text { Government }\end{array}$ & $\begin{array}{c}\text { Majority coalition in the National } \\
\text { Council }\end{array}$ \\
\hline $\begin{array}{c}\text { Government of F. Vranitzky } \\
\text { 4th - 1994-1996 }\end{array}$ & $\begin{array}{c}\text { SPÖ - ÖVP } \\
\text { Governments of the ,new great } \\
\text { coalition” }\end{array}$ & $62,6 \%$ (117 of 183) \\
\hline $\begin{array}{c}\text { GPÖ - ÖVP } \\
\text { 5th - 1996 -1997 }\end{array}$ & $\begin{array}{c}\text { Governments of the ,new great } \\
\text { coalition” }\end{array}$ & $66,4 \%$ (123 of 183) \\
\hline $\begin{array}{c}\text { Government of V. Klima 1st - ÖVP } \\
\text { 1997 - 2000 }\end{array}$ & $\begin{array}{c}\text { Governments of the „new great } \\
\text { coalition” }\end{array}$ & $66,4 \%$ (123 of 183) \\
\hline $\begin{array}{c}\text { Government of W. Schüssel } \\
\text { 1st - 2000 - 2003 }\end{array}$ & ÖVP - FPÖ „,small coalition” & $56,8 \%$ (104 of 183) \\
\hline $\begin{array}{c}\text { Government of Schüssel 2nd - } \\
\text { 2003 -2007 }\end{array}$ & ÖVP - FPÖ „,small coalition” & $53 \%$ (97 of 183) \\
\hline
\end{tabular}


The Europeanisation of the cooperation of the Federal Government...

\begin{tabular}{|c|c|c|}
\hline $\begin{array}{c}\text { Government of A. Gusenbauer } \\
\text { 1st 2007 - 2008 }\end{array}$ & SPÖ - ÖVP great coalition & $73 \%$ (134 of 183) \\
\hline $\begin{array}{c}\text { Government of W. Faymann } \\
\text { 1st - 2008 -2013 }\end{array}$ & SPÖ - ÖVP great coalition & $59 \%(108$ of 183) \\
\hline $\begin{array}{c}\text { Government of W. Faymann } \\
\text { 2nd -2013 - }\end{array}$ & SPÖ - ÖVP great coalition & $54 \%$ (99 of 183) \\
\hline
\end{tabular}

Source: Author's own elaboration based on: https://www.bka.gv.at/site/3355/default.aspx (2.09.2015)

\section{Conclusions}

A result of the integration of Austria into the $\mathrm{EU}$ is marginalisation of the political role of the legislative in EU decision-making processes, which is a consequence of recognising the national executive power as an authority fully legitimate to represent the Member State. The dominance of the Federal Government in the European decision-making processes also partially derives from the efficient selection of the model of coordination of European policy ${ }^{23}$. Another reason for marginalisation of the political role of the legislative in the decision-making processes relating to the $\mathrm{EU}$, along with the simultaneous prominent dominance of the Federal Government in the Austrian governmental system, is the increased significance of populist parties. Euro-sceptic right-wing populist groups in the Austrian political scene undermine the activity of the Federal Government at the European level, pointing to its poor legitimacy. The populist message shows the national Parliament as a weak body, which accepts the activity of the Government in matters related to European integration, and as a consequence the citizens should be able to express their opinions on European matters through referendum. A growing problem emphasised by Ulrich Beck and Edgar Grande is "bureaucratic deformation" of the Europeanisation process, which means a deficit of democracy and legitimacy of the EU seen as consequences of strengthening of governments and transnational actors and, at the same time, weakening the parliaments and democratic participation of citizens in the process of European integration ${ }^{24}$.

\section{BIBLIOGRAPHY}

Barcz Jan. 1999. Parlament a Unia Europejska analiza prawna na przykładzie doświadczeń Austrii. Warszawa: Wydawnictwo Sejmowe.

Barcz Jan. 2001. Austria w Unii Europejskiej. Problemy prawne w procesie akcesyjnym. Opole: Wydawnictwo Uniwersytetu Opolskiego.

Beck Ulrich, Grande Edgar. 2009. Europa kosmopolityczna. Społeczeństwo i polityka w drugiej nowoczesności. Warszawa: Wydawnictwo Naukowe Scholar. 
Börzel Tanja. 2003. Demokratien im Wandel der Europäisierung. W Demokratien in Europa: Der Einfluss der europäischen Integration auf Institutionenwandel und neue Konturen des demokratischen Verfassungsstaates, 181-203. Opladen: Leske +Budrich.

Bundesgesetz über die Geschäftsordnung des Nationalrates (Geschäftsordnungsgesetz 1975) http:// www.ris.bka.gv.at/Dokumente/BgblAuth/BGBLA_2015_I_62/BGBLA_2015_I_62.

Bundesverfassungsgesetz v. 21.12.1994 in der Fassung der Wiederverlautbarung des Bundes-Verfassungsgesetz vom 1. Januar 1930 (in der Fassung vom 7. Dezember 1929) http://www.verfassungen.de/at/at18-34/index29.htm, (1.09.2015).

Falkner Gerda. 2006. Zur „Europäisierung” des österreichischen politischen System W Politik in Österreich. Das Handbuch, 82-94. Wien: Manz Verlag .

Geschäftsordnung des Bundesrates samt Anlage: Verteilungsordnung-EU - VO-EU BGB1. I Nr 141/2011. http://www.parlament.gv.at/PERK/RGES/GOBR/.

Kołodziej Tomasz. 2011. Decydowanie w sprawach stanowiska państwa w relacjach z UE W Decydowanie publiczne. Polska na tle innych państw członkowskich Unii Europejskiej, 309-340. Warszawa: Dom Wydawniczy Elipsa.

Kubuj Katarzyna, Wawrzyniak Jan. 2011. Europeizacja konstytucji państw Unii Europejskiej. Warszawa: Wydawnictwo Naukowe Scholar.

Miecznikowska Justyna. 2009. Unia Europejska a problem koordynacji polityk unijnych - europeizacja administracji publicznej państw członkowskich. W Koordynacja polityk unijnych w Polsce, 2944. Warszawa: Wydawnictwo JR: Aspra.

Müller Wolfgang. 2002. Mitgliedschaft und Regierungshandeln. Präferenzen, Strategien, Institutionen und politische Praxis. W Europäisierung der österreichischen Politik. Konsequenzen der EU -Mitgliedschaft, 101-132. Wien: WUV - Universitätsverlag.

Neisser Heinrich. 2010. Europäisierung durch Parlamentarisierung W Europa als Prozess. 15 Jahre Europäische Union und Österreich. Festschrift für Peter Gerlich, 35-52. Wien: LIT Verlag.

Nowak- Far Artur. 2008 Stosowanie acquis de l’Union przez administrację publiczną państwa członkowskiego. W Administracja publiczna. Wyzwania w dobie integracji europejskiej, 111-134. Warszawa: Wydawnictwa Naukowe PWN.

Pawłowski Szymon. 2011. Zmiany Konstytucji Austrii jako wyraz jej europeizacji W Europeizacja konstytucji państw Unii Europejskiej, 35-58. Warszawa: Wydawnictwo Naukowe Scholar.

Pollak Johannes, Slominski Peter. 2009. „Zwischen De-und Reparlamentarisierung - der österreichische Nationalrat und seine Mitwirkungsrechte in EU-Angelegenheiten”. Österreischische Zeitschrift für Politikwissenschaft 38 (2): 193-212.

Rydlewski Grzegorz. 2007. Systemy administracji publicznej w państwach członkowskich Unii Europejskiej. Warszawa: Dom Wydawniczy Elipsa.

Sarnecki Paweł. 1999. System konstytucyjny Austrii. Warszawa: Wydawnictwo Sejmowe.

Szymanek Jarosław. 2011. Decydowanie parlamentarne. W Decydowanie publiczne. Polska na tle innych państw członkowskich Unii Europejskiej, 70-115. Warszawa: Dom Wydawniczy Elipsa. 
The Europeanisation of the cooperation of the Federal Government...

\section{EUROPEIZACJA WSPÓŁPRACY RZĄDU FEDERALNEGO Z PARLAMENTEM W REPUBLICE AUSTRII - ANALIZA POLITOLOGICZNA}

Przedmiotem niniejszego artykułu jest analiza współpracy rządu federalnego z bikameralnym parlamentem Republiki Austrii w sprawach dotyczących członkostwa państwa w UE. Teza artykułu zakłada, iż parlament w ograniczonym zakresie korzysta z przysługujących mu i zawartych w konstytucji uprawnień w dziedzinie kontroli działań rządu w sprawach dot. członkostwa w UE, co utrwala dominację egzekutywy w unijnych procesach decyzyjnych. W pierwszej kolejności w artykule scharakteryzowano proces adaptacji państwa członkowskiego UE do udziału w procesie decyzyjnym. Następnie przedstawiono rozwiązania przyjęte w Austrii, które w założeniu miały zagwarantować duży stopień kontroli władzy ustawodawczej nad wykonawczą w sprawach integracji europejskiej. Finalnie omówiona została praktyka polityczna wraz ze wskazaniem przyczyn samodzielności rządu federalnego w kształtowaniu polityki europejskiej Austrii.

Słowa kluczowe: Austria, europeizacja, rząd federalny, Rada Narodowa, Rada Federalna, Unia Europejska

Keywords: Austria, Europeanization, Federal Government, National Council, Federal Council, European Union 